\title{
Antitumor function and mechanism of phycoerythrin from Porphyra haitanensis
}

\author{
Qunwen Pan, Meizhen Chen*, Juan Li, Yan Wu, Chao Zhen, Bin Liang \\ Department of Biology and Guangdong provincial key laboratory of Marine Biotechnology, Shantou University, Shantou, Guangdong 515063, China
}

\begin{abstract}
The anti-tumor effect of R-Phycoerythrin (R-PE) from Porphyra haitanensis was studied using cell line HeLa as an in vitro model and Sarcoma-180 (S180) tumor-bearing mice as an in vivo model. The results showed that the combination treatment of R-PE and photodynamic therapy PDT) significantly inhibited the growth of HeLa cells up to $81.5 \%$, with a fair dose-effect relationship, but did not inhibit endothelial cells. The annexin v-fitc/PI fluorescence staining experiments demonstrated that at doses between $0 \sim 60 \mu \mathrm{g} / \mathrm{mL}$, apoptosis cells and later stage apoptosis cells or necrosis cells increased significantly as the R-PE dosage increased. DNA electrophoresis showed that after R-PE+PDT treatment of HeLa cells for 24 hours, a light "smear" band between 100 400bp appeared to indicate the degradation of genomic DNA. The QRT-PCR results showed that R-PE+PDT treatment increased caspase-3 and caspase-10 gene expression and decreased the Bcl-2 gene expression level significantly as the R-PE dose increased, implying that R-PE promoted HeLa cell apoptosis. Compared with untreated S180 tumor-bearing mice, R-PE injection significantly inhibited the growth of S180 in tumor-bearing mice up to $41.3 \%$ at a dose of $300 \mathrm{mg} \cdot \mathrm{kg}^{-1}$. Simultaneously, the significant increase of superoxide dismutase (SOD) activity in serum $(\mathrm{p}<0.01)$ and the decrease of the malondialdehyde (MDA) level in liver suggests that R-PE improved the anti-oxidant ability of the S180 tumor-bearing mice, which may related to its antitumor effect. In addition, the R-PE caused a significant increase $(p<0.05)$ in the spleen index and thymus index, and a significant increase $(\mathrm{p}<0.01)$ in lymphocyte proliferation, NK cell kill activity and the TNF- $\alpha$ level in the serum of S180 tumor-bearing mice. These results strongly suggest that the antitumor effect of R-PE from Porphyra haitanensis functioned by increasing the immunity and antioxidant ability of S180 tumor-bearing mice, promoting apoptosis by increasing protease gene expression and TNF- $\alpha$ secretion.
\end{abstract}

\section{INTRODUCTION}

Phycoerythrin (PE) is an oligomeric protein formed in a $(\alpha \beta)_{6}$ hexamer in an annular architecture. The two different subunits, $\alpha$ and $\beta$, have molecular weights of 17 to $21 \mathrm{KDa}$.. Each $\alpha$ subunit contains 2 phycoerthrobilin (PEB) chromophores which link to Cys82 and Cys139 by a thioester bond. Each $\beta$ subunit contains two PEBs linking to Cys82 and Cys158 and one phycourobilin (PUB) linking to two cysteines, Cys50 and Cys61. The PE hexamers can pile up to form rods which allow the pigment molecules to play an important role in light absorption, storage and transmission. The PE purified from Porphyra haitanensis belongs to $R$ type PE (R-PE), with characteristic absorption peak of $498 \mathrm{~nm}$ from its linked PUB which allows it to play a photosensitive role (1-4).

Photodynamic therapy (PDT), the activation of a tumorlocalized photosensitizer by light, is generally applied as a single modality for the treatment of a variety of solid tumors, and has received regulatory approval. Its dominant mechanism of action is the local generation of cytotoxic singlet oxygen, which causes the destruction of tumor cells and damage to the tumor microvasculature. $\mathrm{PE}$ is an attractive photosensitizer because of its good fluorescence characteristics (2 PEB, 1 PUB) (5-8); it has drawn considerable attention because of its low phototoxicity. Ling $\mathrm{Hu}$ et al. (9) studied the survival rate of the normal liver cell line HL7702 and liver cancer cell line HepG2 after treatment with $25 \sim 200 \mu \mathrm{g} / \mathrm{mL}$ of the $\beta$ subunit of PE. Comparison of PE in four different treatments, PE subunit alone (PE-sub), PE subunit with liposome package (PE-sub-lip), PE subunit with laser irradiation (PE-sub-PDT) and PE subunit with liposome package and laser irritation (PE-sub-lip-PDT), demonstrated that the use of the liposome carrier increased the PE-sub accumulation in the cells and enhanced its PDT effect on HepG2.

Caspase is a special family of proteases which play a central role in programmed cell apoptosis (10). Caspases can degrade anti-apoptotic protein and induce the release of mitochondrial cytochrome C. At the same time, caspase-mediated degradation can weaken the function of DNAase inhibitor ICAD (inhibitor of caspase DNAase), thus increasing intracellular $\mathrm{Ca}^{2+}$ concentration, activating DNAase and encouraging the fragmentation of DNA as depicted in Fig. 1 (11-14).

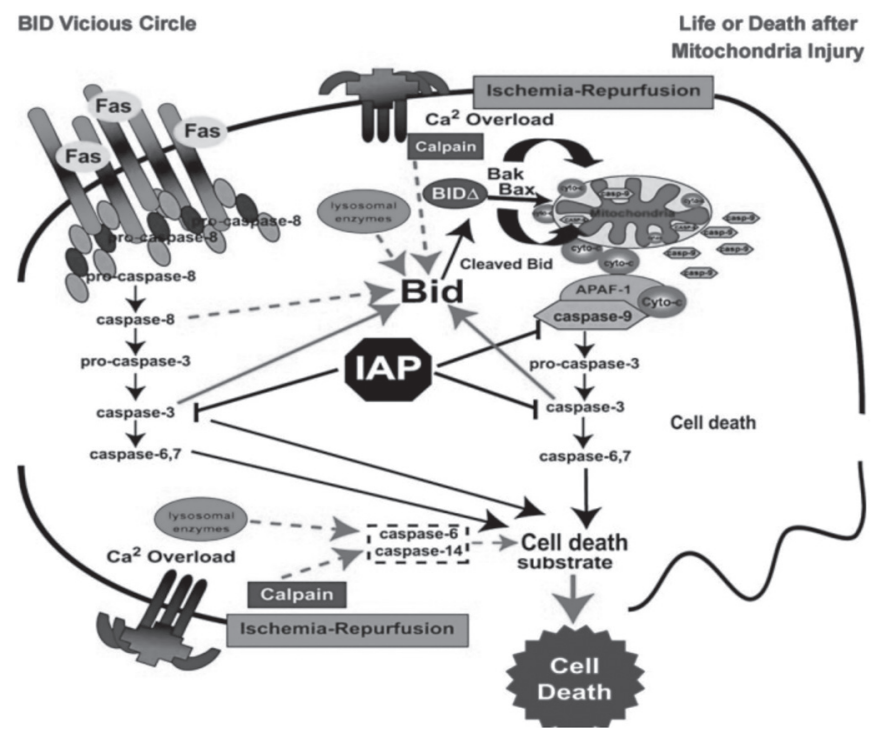


Fig. 1. Graphic summary of events after global brain ischemia during reperfusion. The activation of major, caspasedependant apoptosis pathways, the possible cross-talk between necrosis-inducing cytoplasmic-lysosomal proteases and their possible interaction with Bcl-2 and caspase protein families are depicted (12).

The objective of this investigation was to study the in vivo and in vitro anti-tumor effect of R-PE from Porphyra haitanensis. The results showed that R-PE had a strong in vivo and in vitro anti-tumor effect, and that PDT can improve the in vitro anti-tumor effect of R-PE. These results may provide a basis for developing the PE into a photosensitive drug for cancer therapy.

\section{MATERIALS AND METHODS}

PE from Porphyra haitanenis (R-PE), with food grade purity (A565/A280>0.7) and drug class purity (A565/A280>2.0) was obtained in the laboratory. The cervical carcinoma cell line HeLa, mouse ascitic tumor cell line S180 and KM mice (qualified number: SCXKG Fujian 2004-0001) were obtained from the animal center of Xiamen University, Xiamen, China. Concanavalin (ConA) and MTT was purchased from Sigma (St Louis, MO, USA).

\subsection{Extraction and purification of phycoerythrin}

Fresh Porphyra haitanenis was washed with 1 M PBS buffer $(\mathrm{pH}$ 6.8). One volume of washed algal mass was resuspended in fifteen volumes of the same buffer and subjected to repeated freeze-thaw cycles of $-20{ }^{\circ} \mathrm{C}$ and $4{ }^{\circ} \mathrm{C}$ for the release of PE. Purification was done by two-step ammounium sulphate precipitation (25\% and 55\%) followed by chromatography using a gel sephadex G-100 column $(60 \mathrm{~cm} \times 2 \mathrm{~cm})$ pre-equilibrated and eluted with $10 \mathrm{mM}$ PBS buffer $(\mathrm{pH} 7.0)$. The flow rate was maintained at $45 \mathrm{ml} \cdot \mathrm{h}^{-1}$. Elute was collected and run through a DEAE-Cellulose ion exchange column $(30 \mathrm{~cm} \times 2 \mathrm{~cm})$ preequilibrated with 20mM PBS buffer (pH6.0). The R-PE rich fraction was eluted at $0.2 \mathrm{M} \mathrm{NaCl}$. The R-PE was stored at -20 ${ }^{\circ} \mathrm{C}$. At each stage of purification the R-PE purity and molecular weight were determined by $12 \%$ SDS-PAGE (Fig. 1). The R-PE purity measured as the ratio of OD565/OD280 was also determined at each stage of purification (Table 2). The UV-vis overlay spectrum for purified R-PE is shown in Fig. 2.

\subsection{R-PE PDT effect on HeLa cells}

\subsubsection{Cell culture}

Cervical carcinoma line HeLa was routinely grown in Dulbecco's Modified Eagle's medium (DMEM) supplemented with $10 \%$ fetal bovine serum and $1 \%$ penicillin/streptomycin and kept in an atmosphere of $95 \%$ air and $5 \% \mathrm{CO}_{2}$ in a $37{ }^{\circ} \mathrm{C}$ humidified incubator.

\subsubsection{PDT}

In total, $5 \times 10^{4} / \mathrm{mL}$ cells were inoculated in 96-well plates with serum-free DMEM and treated with $0,3.5,7,15,30$ or $60 \mu \mathrm{g} /$ $\mathrm{mL}$ R-PE for $4 \mathrm{~h}$ before laser irradiation. The PDT excitation wavelength was $632.8 \mathrm{~nm}$ and energy intensity was $12.5 \mathrm{~J} /$ $\mathrm{cm}^{2}$ laser light; the two kinds of cells were cultured in DMEM containing $10 \%$ serum for $24 \mathrm{~h}$ and $48 \mathrm{~h}$, respectively. Each concentration was repeated 6 times, along with a blank control (without R-PE or laser light irradiation) and a positive control group (treated with $20 \mu \mathrm{g} / \mathrm{mL} 5$-fluorouracil). The survival rate of the PDT-treated HeLa cell lines was analyzed using the 3-(4, 5-dimethylthiazol-2-yl)-2,5-diphenyltetrazolium bromide assay.

Cell survival rate $(\%)=\mathrm{OD}$ experimental group $/ \mathrm{OD}$ blank group $\times 100 \%$

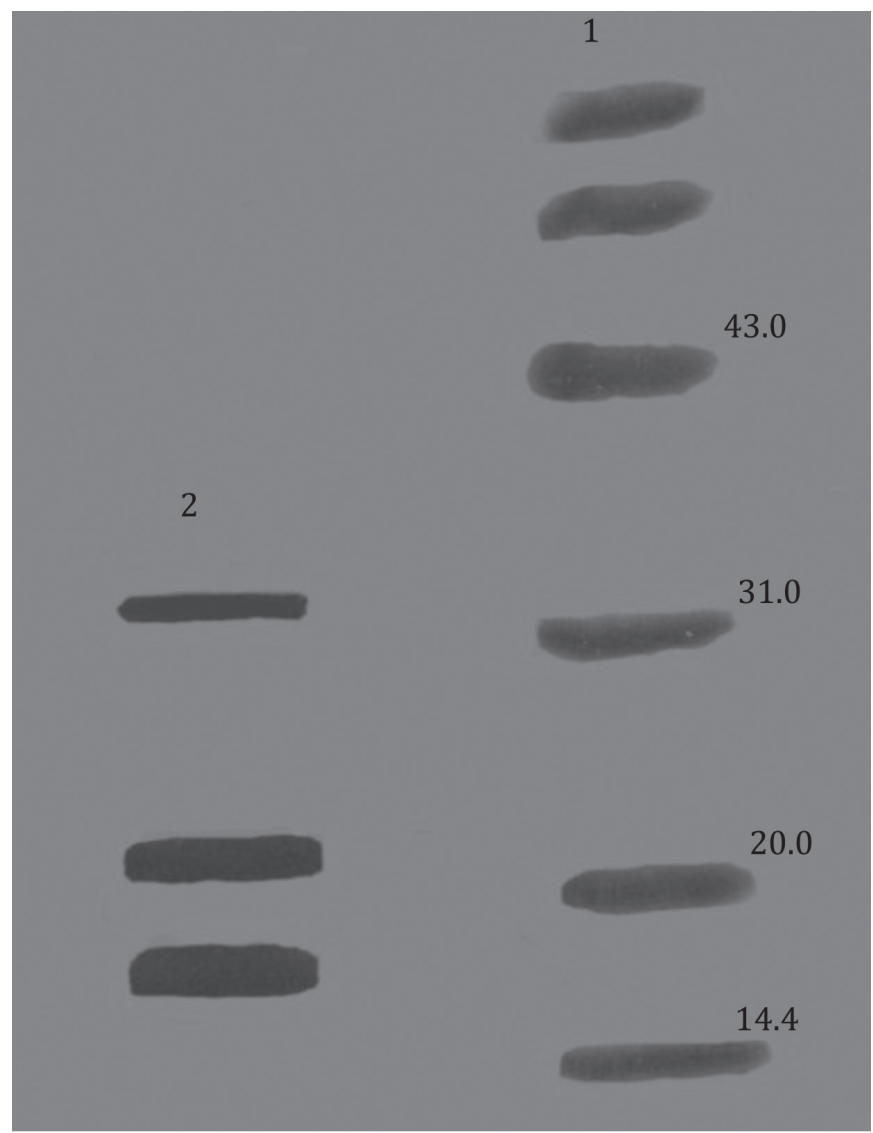

Fig.1. Molecular weight determination of Porphyra haitanensis R-PE on $12 \%$ SDS-PAGE. Lines: 1 , protein molecular mass standard in $\mathrm{kDa}$; 2,R-PE purified from Porphyra haitanensis (purity, A565/ $\mathrm{A} 280=3.3$ )

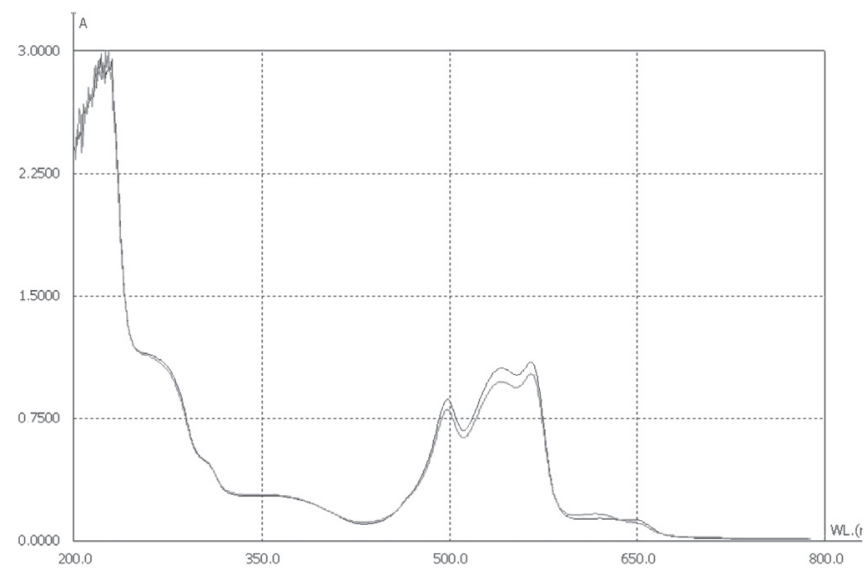

Fig.2. UV-vis overlay spectrum of R-PE 
2.2.3. Cell apoptotic analysis by Annexin V-FITC / PI double fluorescent

At the exponential phase stage, $5 \times 10^{5} / \mathrm{mL}$ cells were inoculated in 24-well plates with serum-free DMEM and treated with $0,15,30$ or $60 \mu \mathrm{g} / \mathrm{mL}$ R-PE for $4 \mathrm{~h}$ before laser irradiation. The PDT excitation wavelength was $632.8 \mathrm{~nm}$ and energy intensity was $12.5 \mathrm{~J} / \mathrm{cm}^{2}$ laser light. The negative control and positive control groups were set up with treatments of 15,30 or $60 \mu \mathrm{g} / \mathrm{mL}$ R-PE and with $20 \mu \mathrm{g} / \mathrm{mL}$ 5-fluorouracil. The cells were cultured in DMEM containing $10 \%$ serum for $24 \mathrm{~h}$. After the cells were washed with cold 10 mM PBS, Annexin V-FITC / PI double fluorescence dyeing liquid was added and the plates were placed in the dark for 15 min. The morphology of the HeLa cells was examined under a fluorescence microscope.

\subsubsection{RNA isolation and cDNA synthesis}

Total RNA was extracted from HeLa cells treated with 0, 15, 30 or $60 \mu \mathrm{g} / \mathrm{mL}$ R-PE for $4 \mathrm{~h}$ before laser irradiation, using an RNAiso plus kit according to the manufacturer's instructions. Each concentration was repeated 3 times. The extracted RNA was treated with RNase-Free DNase to remove contaminating DNA, and cDNA was synthesized using the PrimeScript RT Reagent Kit following the manufacturer's instructions.

2.2.5. mRNA expression of caspase and Bcl-2

Caspase and Bcl-2 cDNA were amplified from the extracted total RNA $(2 \mu \mathrm{g})$ using primers caspase-F, caspase-R and Bcl-2-F, Bcl-2-R, respectively (Table 1), under the following conditions: pre-denaturation at $95{ }^{\circ} \mathrm{C}$ for $2 \mathrm{~min}, 30$ cycles of

TABLE 1

Nucleotide sequence of primers

\begin{tabular}{ll}
\hline primer & Sequence(5' $\left.{ }^{\prime} \mathbf{3}^{\prime}\right)$ \\
\hline Caspase-3-F & GGTTCATCCAGTCGCTTTG \\
Caspase-3-R & GCTTTCCACCGTTGTCTC \\
Caspase-10-F & GTATCAGGCTACCCAGTCC \\
Beta-actin-F & GTTGCGTTACACCCTTTC \\
Beta-actin-R & CTTGCCACTTCCACTGTC \\
Bcl-2-R & GTTCTTCGACTCGCTCAC \\
\hline
\end{tabular}

$95{ }^{\circ} \mathrm{C}$ for $30 \mathrm{~s}, 60{ }^{\circ} \mathrm{C}$ for 30 s, followed by a final elongation at $74{ }^{\circ} \mathrm{C}$ for $5 \mathrm{~min}$. As an internal control, a crab beta-actin cDNA fragment was amplified with primers beta-actin- $F$ and betaactin-R (Table 1) and the same PCR amplification conditions.

\section{3. Anti-tumor activity of R-PE on S180 tumor-bearing mice}

\subsubsection{Model establishment of S180 sarcoma}

S180 tumor cells in mice were reproduced by ascites serial passage 3 times, 7 days per passage. S180 tumor cells were extracted from the last tumor-bearing mice under sterile conditions. The cell concentration was adjusted to $1.4 \times 10^{7} / \mathrm{mL}$ with cold sterile saline, then $0.2 \mathrm{~mL}$ cell suspension fluid was inoculated in the left fore oxter of the mice.

2.3.2. Experimental design Male mice ( $28 \pm 2 \mathrm{~g} /$ mouse) were used in the experiments. Seventy two mice were arranged into six groups $(n=12)$ : The blank group served as a normal control and received distilled water at level of $0.2 \mathrm{ml} /$ day for 9 days. The model group served as an S180 sarcoma group and received distilled water at level of $0.2 \mathrm{ml} /$ day for 9 days. The positive drug group served as an S180 sarcoma group and received 5-FU $\left(20 \mathrm{mg} \cdot \mathrm{Kg}^{-1} \mathrm{bw} \cdot \mathrm{d}^{-1}\right)$ (15) for 9 days. The R-PE low-dose group served as an S180 sarcoma group and received R-PE $\left(100 \mathrm{mg} \cdot \mathrm{Kg}^{-1} \mathrm{bw} \cdot \mathrm{d}^{-1}\right)$. The R-PE middle-dose group served as an S180 sarcoma group and received R-PE $(200 \mathrm{mg} \cdot \mathrm{Kg}$ $\left.{ }^{1} \mathrm{bw} \cdot \mathrm{d}^{-1}\right)$. The R-PE high-dose group served as an S180 sarcoma group and received $\mathrm{R}-\mathrm{PE}\left(300 \mathrm{mg} \cdot \mathrm{Kg}^{-1} \mathrm{bw} \cdot \mathrm{d}^{-1}\right)$. The mice were weighed every other day. At the end of the 9-day treatment, mice were sacrificed. Blood was collected using the eye socket and centrifuged at $1000 \times \mathrm{g}$ for $10 \mathrm{~min}$. Serum was collected for antioxidative experiments and analyzed for TNF-acontent. Liver and spleen were excised and used for antioxidative and cellular immunity experiments.

\subsubsection{Tumor inhibitory rate and immune organ index}

The tumor inhibitory rate and the immune organ index were calculated with the following formulae:

Tumor inhibitory rate $(\%)=$ tumor weight of text group / tumor weight of blank group $\times 100 \%$

Immune organ index $(\mathrm{mg} / 10 \mathrm{~g})=$ weight of organs $(\mathrm{mg}) /$ weight of mouse $(10 \mathrm{~g}) \times 100 \%$

\section{TABLE 2}

Total protein concentration and spectroscopic purity of Porphyra haitanensis R-PE at each stage of purification

\begin{tabular}{lcccc}
\hline \multicolumn{1}{c}{ Purification step } & $\begin{array}{c}\text { Purity } \\
\left(\mathrm{OD}_{\mathbf{5 6 5}} / \mathrm{OD}_{\mathbf{2 8 0}}\right)\end{array}$ & $\begin{array}{c}\text { Quantity } \\
(\mathbf{m g})\end{array}$ & $\begin{array}{c}\text { Yield } \\
(\mathbf{m g} / \mathbf{g})\end{array}$ & $\begin{array}{c}\text { Recovery } \\
(\%)\end{array}$ \\
\hline Crude repeated freeze-thaw extract & 0.56 & 342.6 & 11.42 & 5.78 \\
Two step salting-out extraction & 1.39 & 173.4 & 58.11 & 1.94 \\
SephadexG-100 chromatography & 2.45 & 50.42 & 1.68 & 83.51 \\
ion-exchange chromatography & 3.30 & & 86.69 \\
\hline
\end{tabular}




\subsubsection{SOD activity and MDA content analysis}

SOD enzyme activity and the MDA content in liver and serum were determined using the commercial kit according to the manufacturer's instructions.

2.3.5. Splenic lymphocyte proliferation capacity of tumor-bearing mice

Spleen cells were prepared in sterile conditions and were diluted to $2 \times 10^{6} / \mathrm{mL}$ with the complete culture medium. The cell suspension liquid was inoculated in 96-well plates, $200 \mu \mathrm{L}$ per well, 4 wells with each treatment group; three of them with $5 \mu \mathrm{L} 200 \mathrm{mg} / \mathrm{ml}$ ConA (final concentration 5 $\mathrm{mg} / \mathrm{l}$ ) and one well set as blank control with $5 \mu \mathrm{L}$ of the same complete culture medium. The plates were incubated for $3 \mathrm{~d}$. $100 \mu \mathrm{L}$ of supernatant liquid per well was taken $4 \mathrm{~h}$ before the end of the incubation. After adding $20 \mu \mathrm{L}$ of MTT solution $(5 \mathrm{mg} / \mathrm{ml})$, the plates were incubated for 4 more hours. The proliferation capacity of spleen lymphocytes was analyzed using 3-(4,5-dimethylthiazol-2-yl)-2,5-diphenyltetrazolium bromide assay $(16,17)$.

Lymphocyte proliferation capacity $(\%)=\left(\mathrm{OD}_{\mathrm{ConA}}\right.$ treated group ${ }^{-}$ $\mathrm{OD}_{\text {control group }}$ )

\subsubsection{Natural killing activity of NK cells}

Spleen cells were prepared in sterile conditions as the effector cell and were diluted to $2 \times 10^{7} / \mathrm{mL}$ with the complete culture medium. HeLa cells were prepared as the target cell and were diluted to $2 \times 10^{5} / \mathrm{mL}$ with the complete culture medium. 100 $\mu \mathrm{L}$ of the target cell suspension liquid was inoculated in 96well plates and 4 wells for each treatment group and cultivated for $8 \mathrm{~h}$. The isopycnic effector cells were added in three wells per group, adjusting the ratio of effector cells to target cells to 100 to 1 . The remaining wells were set as two control groups of the target cell and the effector cell wells. The cells were incubated in an incubator at $37{ }^{\circ} \mathrm{C}$ with $5 \% \mathrm{CO}_{2}$ for 4 h. Cell survival rate was determined by MTT assay(18) using the following formula.

Natural killing activity of NK cells $(\%)=[\mathrm{OD}$ target cell group - $(\mathrm{OD}$ target cell treated with effector cell group $-\mathrm{OD}$ effector cell group $)] / \mathrm{OD}_{\text {target cell }}$ group

2.3.7. TNF- $\alpha$ secretion capacity of the spleen cells

TNF- $\alpha$ secretion capacity of the spleen cells in mice was determined using enzyme-linked immunosorbent assay (ELISA) according to manufacturer instructions.

\subsubsection{Histopathology}

The tumor specimens were examined microscopically after routine preparation (19). The tumor-bearing mice treated with 5-FU and different concentrations of R-PE were sacrificed 9 days after establishment of the S180 sarcoma model. Tumors were fixed using $10 \%$ neutral buffered formalin solution for $24 \mathrm{~h}$ and then dehydrated in a series of different concentrations of ethanol, infiltrated with xylene and paraffin and embedded in paraplast. The specimens were serially sectioned ( $6 \mu \mathrm{m}$ thickness) with a microtome and stained on microscope slides using haematoxylin and eosin (H\&E). The stained slides were observed and photographed using a fluorescence microscope (20).

\subsubsection{Statistical analysis}

Data were expressed as mean \pm 1 SD for at least three experiments. Student's t-test was used to compare data. The data with $\mathrm{P}<0.05$ were considered to be statistically significant.

\section{RESULTS}

\subsection{Extraction and purification of $R-P E$}

The purity and homogeneity of the R-PE extracted from Porphyra haitanensis were examined using spectroscopic methods and denaturing gel electrophoresis (Table 2 and Figs. 1 and 2). The purified protein had three subunits, $\alpha, \beta$ and $\gamma$, corresponding to molecular weights of 18,23 and 33KDa, and had its absorbance maximum at $565 \mathrm{~nm}$ wavelength.

\subsection{R-PE PDT effect on HeLa cells}

In order to study R-PE as a photosensitizer on HeLa cells and its cell toxicity in normal cells, we treated cells with different purity and concentrations of R-PE for $4 \mathrm{~h}$ and irradiated them with $12.5 \mathrm{~J} / \mathrm{cm} 2$ of HE-NE laser. As shown in Table 3 , at a concentration of $60 \mu \mathrm{g} / \mathrm{mL}$ and purity ratio of 3.3, the combination of $4 \mathrm{~h}$ incubation with the R-PE and laser irradiation resulted in cytotoxicity, where $18.6 \% \pm 0.59 \%$ of the HeLa cells survived, which is $34 \% \pm 0.32 \%$ ( $n=6, p<0.01$ ) less than the same treatment but without laser irradiation and $1.5 \% \pm 0.12 \%$ less than 5 -FU group. The half lethal dose of R-PE (purity 2.45) for the R-PE+PDT treatment was approximately $15 \mu \mathrm{g} / \mathrm{mL}$. At this concentration the survival rate of HeLa reached $73.5 \% \pm 1.63 \%$ without laser irradiation. Cell death induced by R-PE on normal endothelial cells after R-PE+PDT treatment was examined at $3.5-60 \mu \mathrm{g} / \mathrm{mL}$ of R-PE. The results showed that R-PE has low cell toxicity on normal cells and good tumor-targeting characteristics.

As shown in Table 4, when R-PE was incubated with the cells during rinsing with PBS and cells were then irradiated with laser, no cytotoxicity was observed. These results revealed that the laser irradiation $(12.5 \mathrm{~J} / \mathrm{cm} 2)$ alone produced no cytotoxicity.

\subsection{Apoptotic analysis of R-PE+PDT-treated cells}

To investigate the R-PE+PDT effect on cell apoptosis, HeLa cells treated with R-PE alone and the combination of PDT and different concentrations of R-PE $(15,30$ or $60 \mu \mathrm{g} / \mathrm{mL})$ were harvested for morphological observation. As shown in Fig. 3, the blank group of HeLa cells showed tight connections (Figs 3a, 3e); after R-PE treatment the cells became more separated and loosely arranged with increasing concentration of R-PE (Figs.3b, 3c, 3d). The combination treatments of R-PE and PDT changed HeLa cells into oval cells in suspension. A large number of cells lysed (Fig. 3h) after the treatment with the highest concentration of R-PE $(60 \mu \mathrm{g} / \mathrm{mL})$ and PDT.

For morphological observation of the PDT-treated cells, the cells were stained with annexin V-FITC and propidium iodide and examined under a fluorescence microscope. The 
green fluorescent spots represent viable apoptotic cells and the red fluorescent spots represent non-viable apoptotic cells. As shown in Fig. 4, the non-viable apoptotic cells increased as the concentration of the R-PE increased (Fig. 4b, 4c, 4d), and the additional PDT treatment significantly enhanced the effect.

\subsection{Expression of caspase-3, casapse-10 and Bcl-2 mRNA}

Expressions of Caspase-3, Caspase-10 and Bcl-2 mRNA were determined using RT-PCR. As shown in Fig. 5, with increasing concentrations of R-PE Caspase-3 and the Caspase-10 mRNA transcription increased. In contrast, Bcl-2 mRNA transcription decreased as the concentration of R-PE increased.

A quantitative real-time PCR assay was carried out to determine the transcript levels of Caspase-3, Caspase-10 and Bcl-2 in HeLa cells after R-PE+PDT treatment. Caspase-3 mRNA expression increased with increasing concentration of R-PE. At the concentration of $60 \mu \mathrm{g} / \mathrm{mL}$ R-PE Caspase-3 mRNA increased 22.1-fold in comparison to the control (Fig. $6 \mathrm{~A})$. However, the transcript levels of Caspase-10 mRNA were unchanged until the concentration of R-PE reached $60 \mu \mathrm{g} / \mathrm{mL}$, where the Caspase-10 mRNA expression increased 8.45-fold in comparison to the control (Fig. 6C). In contrast, Bcl-2 mRNA decreased significantly with increasing concentration of R-PE. At the concentration of $60 \mu \mathrm{g} / \mathrm{mL}, \mathrm{Bcl}-2 \mathrm{mRNA}$ expression decreased 0.15-fold compared to the control (Fig. 6B). All these results were consistent with results shown in Fig. 5.

\subsection{Inhibitory effect of R-PE on S180 tumor-burdened mice}

As shown in Table 5, the inhibition effect of R-PE on S180 had an obviouse dose effect. The R-PE in the high dose group $\left(300 \mathrm{mg} \cdot \mathrm{Kg}^{-1} \mathrm{bw} \cdot \mathrm{d}^{-1}\right)$ showed much greater tumor inhibition rate, $41.3 \% \pm 1.22 \%(\mathrm{n}=12, \mathrm{p}<0.01)$, than the $7.89 \pm 0.44$ in the $5-\mathrm{FU}$
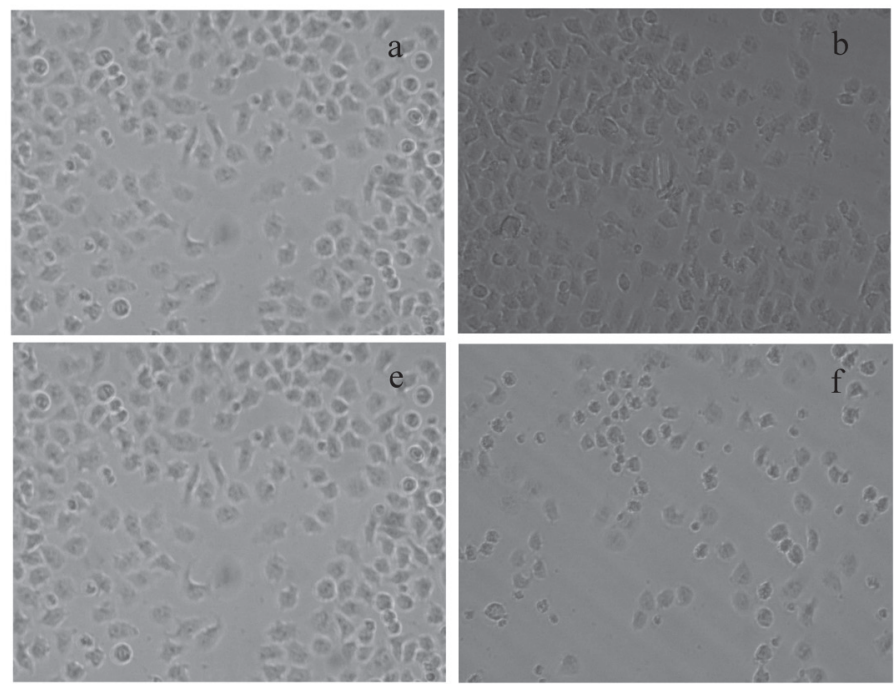
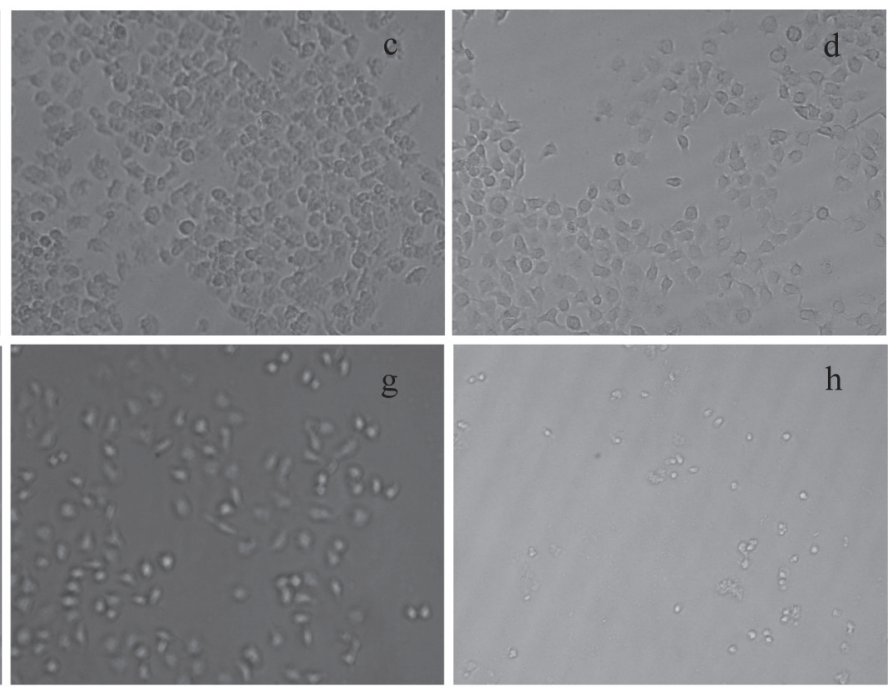

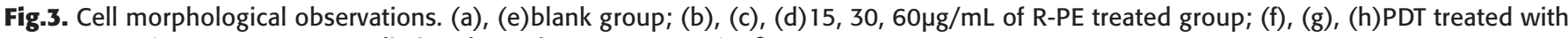
$15,30,60 \mu \mathrm{g} / \mathrm{mL}$ R-PE group. Irradiation dose of PDT was $12.5 \mathrm{~J} / \mathrm{cm}^{2}$
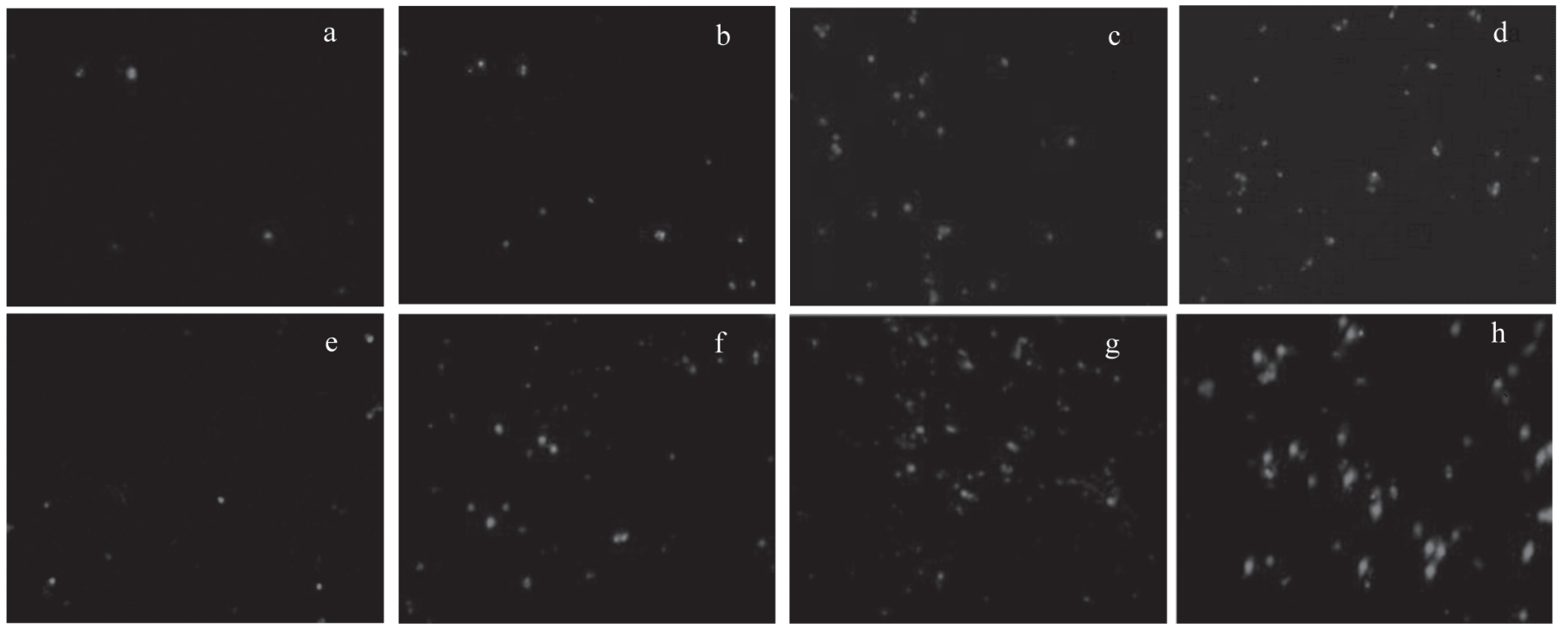

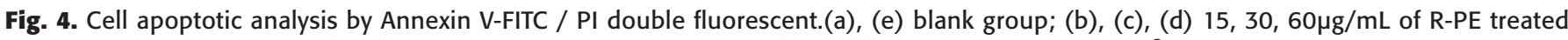
group; (f), (g), (h)PDT treated with 15, 30,60 $\mathrm{g} / \mathrm{mL}$ R-PE group. Irradiation dose of PDT was $12.5 \mathrm{~J} / \mathrm{cm}^{2}$ 
TABLE 3

PDT effect of R-PE on HeLa cell line. $n=6$. Mean \pm SD. The blank group was the control. ${ }^{*} P<0.01$ vs. control

\begin{tabular}{|c|c|c|c|c|c|c|}
\hline \multirow{3}{*}{ Group } & \multicolumn{6}{|c|}{ Cell survival rate(\%) } \\
\hline & \multicolumn{4}{|c|}{ HeLa cells } & \multicolumn{2}{|c|}{ Endothelial cells } \\
\hline & $24 \mathrm{~h}$ & PDT(24h) & $48 \mathrm{~h}$ & PDT(48h) & $24 \mathrm{~h}$ & $48 \mathrm{~h}$ \\
\hline Blank & $100.0 \pm 0.00$ & $100.0 \pm 0.00$ & $100.0 \pm 0.00$ & $100.0 \pm 0.00$ & $100.0 \pm 0.00$ & $100.0 \pm 0.00$ \\
\hline 5-FU & $23.9 \pm 3.47$ & $22.1 \pm 4.12$ & $19.3 \pm 1.56$ & $20.1 \pm 0.47$ & $38.9 \pm 0.31$ & $32.6 \pm 1.87$ \\
\hline \multicolumn{7}{|c|}{ Concentration of R-PE $(\mu \mathrm{g} / \mathrm{ml})$, purity ratio 0.56} \\
\hline 3.5 & $97.9 \pm 0.31$ & $96.3 \pm 1.42$ & $94.8 \pm 3.11$ & $93.9 \pm 1.44$ & $97.8 \pm 0.06$ & $98.1 \pm 0.04$ \\
\hline 7.0 & $94.8 \pm 1.33$ & $90.3 \pm 1.53$ & $90.7 \pm 0.89$ & $74.6 \pm 3.71$ & $96.3 \pm 0.0,9$ & $98.2 \pm 0.14$ \\
\hline 15 & $87.9 \pm 0.24$ & $86.4 \pm 1.41$ & $84.5 \pm 1.81$ & $71.8 \pm 2.99^{*}$ & $96.4 \pm 0.07$ & $97.3 \pm 0.05$ \\
\hline 30 & $86.9 \pm 1.22$ & $72.9 \pm 3.11$ & $83.3 \pm 1.76$ & $59.4 \pm 2.22^{*}$ & $94.5 \pm 0.05$ & $97.7 \pm 0.35$ \\
\hline 60 & $82.1 \pm 0.40$ & $59.1 \pm 7.87$ & $78.2 \pm 0.59$ & $47.1 \pm 0.79^{*}$ & $90.0 \pm 0.06$ & $93.8 \pm 0.25$ \\
\hline \multicolumn{7}{|c|}{ Concentration of R-PE $(\mu \mathrm{g} / \mathrm{ml})$, purity ratio 2.45} \\
\hline 3.5 & $93.4 \pm 2.36$ & $84.7 \pm 0.18$ & $89.1 \pm 2.16$ & $83.5 \pm 0.89$ & $98.3 \pm 0.12$ & $98.7 \pm 0.04$ \\
\hline 7 & $82.7 \pm 5.01$ & $71.6 \pm 0.67^{*}$ & $84.2 \pm 2.08$ & $71.9 \pm 0.51^{*}$ & $97.2 \pm 0.22$ & $98.1 \pm 0.10$ \\
\hline 15 & $74.9 \pm 10.9$ & $52.4 \pm 2.72^{*}$ & $73.5 \pm 1.63$ & $48.2 \pm 1.30^{*}$ & $97.5 \pm 0.09$ & $97.8 \pm 0.11$ \\
\hline 30 & $69.9 \pm 4.64^{*}$ & $33.9 \pm 0.75^{*}$ & $58.6 \pm 1.14^{*}$ & $29.3 \pm 0.27^{*}$ & $96.7 \pm 0.15$ & $96.9 \pm 0.08$ \\
\hline 60 & $57.4 \pm 2.20^{*}$ & $20.9 \pm 0.86^{*}$ & $52.5 \pm 0.91^{*}$ & $18.6 \pm 0.59^{*}$ & $92.1 \pm 0.08$ & $95.8 \pm 0.32$ \\
\hline
\end{tabular}

Irradiation dose of PDT was $12.5 \mathrm{~J} / \mathrm{cm}^{2}$

TABLE. 4

HeLa cell survival rate irradiated with laser

\begin{tabular}{|c|c|c|}
\hline \multirow{2}{*}{ Laser intensity $\left(\mathrm{J} / \mathrm{cm}^{2}\right)$} & \multicolumn{2}{|c|}{ Cell survival rate $(\%)$} \\
\hline & \multicolumn{2}{|c|}{$24 \mathrm{~h} 48 \mathrm{~h}$} \\
\hline 0.00 & $100.00 \pm 0.00$ & $100.00 \pm 0.00$ \\
\hline 12.50 & $97.20 \pm 2.38$ & $98.70 \pm 3.12$ \\
\hline
\end{tabular}

Irradiation dose of PDT was $12.5 \mathrm{~J} / \mathrm{cm}^{2}$

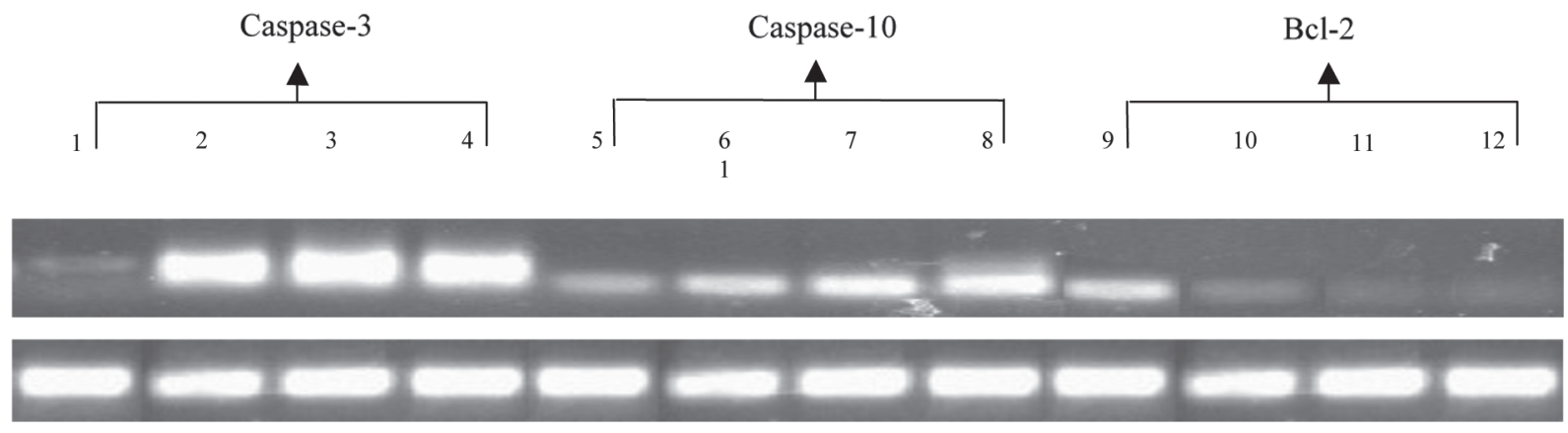

Fig. 5. Detection of Caspase-3, Caspase-10 and Bcl-2 mRNA transcripts in PDT-treated HeLa cells. Total RNA was isolated from HeLa cells for RT-PCR analysis using the Caspase-3, Caspase-10 and Bcl-2 gene-specific primers. The Beta-actin gene was used as a control. Line 1-4, 5-8 and 9-10 all represent 0, 15, 30 and $60 \mu \mathrm{g} / \mathrm{mL}$ R-PE PDT-treated HeLa cells. 
$\left(20 \mathrm{mg} \cdot \mathrm{Kg}^{-1} \mathrm{bw} \cdot \mathrm{d}^{-1}\right)$ treatment group. Furthermore, R-PE appeared to have a significant protection role rather than a harmful role to immune organs of tumor-bearing mice in 5-FU treatment.

In comparison to the model group, R-PE significantly improved SOD enzyme activity and reduced the content of MDA in mice. SOD enzyme activity in the R-PE treatment group was greater than the blank group and reached 109.24 $\pm 30.89 \mathrm{U} / \mathrm{mL}$.

As shown in Table 5, R-PE increased the rate of lymphocyte production. The lymphocyte prolifiration ratio increased by $66.7 \% \pm 4.47 \%$ for the R-PE high dose group. Furthermore, the $\mathrm{R}-\mathrm{PE}$ high dose group significantly improved the killing activity of NK cells $(\mathrm{n}=12, \mathrm{p}<0.01)$ on HeLa cells, up to $41.13 \% \pm 3.74 \%$.

R-PE also significantly irritated the secretion of TNF- $\alpha$ by mononuclear macrophages in tumor-bearing mice $(n=12$, $\mathrm{p}<0.01)$.

\subsection{Histopathology of the S180 sarcoma sections of the mice}

As shown in Fig. 7, the tumor cells in the model group were mononucleated or multinucleated in a large dense patch. Tumor giant cells and the nucleus were hyperchromatic, nuclear division was easy to see and small tumor cells were observed in the cytoplasm.The tumor infiltration of the soft tissue was deep, and less fibrous tissues were observed in the tumor tissue. In contrast, the tumor cells in R-PE treatment group were arranged loosely, and tumor giant cells decreased significantly. Very little tumor infiltration of tumor biopsies was observed. The fibrous tissue increased significantly as the concentration of R-PE increased. A large number of lymphocytes and macrophages were observed to infiltrate into the tumor tissue to kill the tumor cells. Therefore, R-PE showed significant antitumor effect and obviously had a dose effect.

TABLE. 5

Effect of R-PE on the immune ability of mice bearing S180 sarcoma

\begin{tabular}{|c|c|c|c|c|c|c|}
\hline Group & Normal & Model & 5-FU & R-PE(LD) & R-PE(MD) & R-PE(HD) \\
\hline Liver index $(\mathrm{mg} / 10 \mathrm{~g})$ & $474.49 \pm 19.11$ & $539.17 \pm 39.31$ & $567.86 \pm 25.43$ & $539.48 \pm 25.46$ & $564.50 \pm 139.59$ & $572.61 \pm 12.11$ \\
\hline Spleen index $(\mathrm{mg} / 10 \mathrm{~g})$ & $41.71 \pm 1.74$ & $62.21 \pm 2.75$ & $52.19 \pm 3.10$ & $61.90 \pm 1.75$ & $69.67 \pm 2.02$ & $76.46 \pm 2.46^{b}$ \\
\hline Thymus index(mg/10g) & $36.58 \pm 2.12$ & $24.33 \pm 1.56$ & $15.89 \pm 0.91^{b}$ & $35.57 \pm 2.31^{b}$ & $28.90 \pm 1.26$ & $27.09 \pm 2.40$ \\
\hline \multicolumn{7}{|l|}{ serum } \\
\hline $\operatorname{MDA}(\mathrm{mmol} / \mathrm{mL})$ & $4.33 \pm 0.41$ & $8.54 \pm 0.37^{\text {aa }}$ & $7.01 \pm 1.49$ & $6.77 \pm 1.09$ & $6.57 \pm 0.19$ & $6.57 \pm 0.35$ \\
\hline \multicolumn{7}{|l|}{ Liver } \\
\hline $\mathrm{SOD}(\mathrm{U} /$ mgprot $)$ & $280.82 \pm 18.22$ & $263.58 \pm 12.42$ & $253.48 \pm 12.66$ & $267.12 \pm 10.46$ & $278.09 \pm 11.17$ & $289.64 \pm 18.58$ \\
\hline MDA(nmol/mgprot) & $8.40 \pm 0.53$ & $10.90 \pm 0.34$ & $8.35 \pm 0.24$ & $6.87 \pm 0.28$ & $5.40 \pm 0.57^{\mathrm{b}}$ & $4.70 \pm 0.18^{\mathrm{bb}}$ \\
\hline
\end{tabular}

Values are expressed as mean \pm SD for twelve mice in each group. One-way ANOVA repeated measures with Duncan's multiple range test was used to calculate statistical significance.

a Indicates statistical significance of $\mathrm{p}<0.05$ compared to the Normal group;

aa $p<0.01$ compared to the Normal group;

b $p<0.05$ compared to the Model group.

b b $p<0.01$ compared to the Model group.

(A)

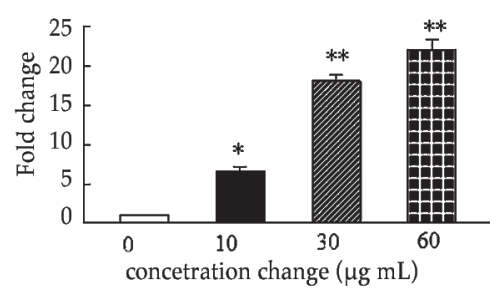

(B)

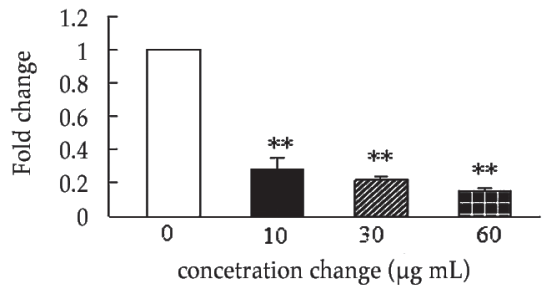

(C)

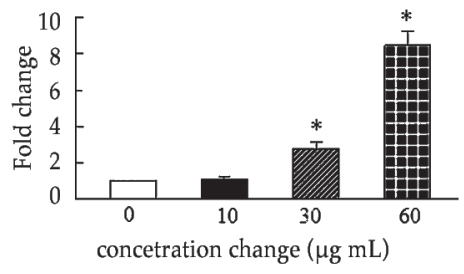

Fig. 6 Quantitative real-time PCR analysis of Caspase-3(A), Caspase-10 (C)and Bcl-2 (B)mRNA transcripts in PDT-treated HeLa cell after treated with 0, 10, 30 and $60 \mu \mathrm{g} / \mathrm{mL}$ R-PE.Caspase-3, Caspase-10 and Bcl-2 mRNA levels were normalized with beta-actin mRNA levels. Bars represented the mean $\pm S D(n=3)$.significant differences between R-PE PDT-treated and the control were indicated with one ( $p<$ $0.05)$ or two $(p<0.01)$ asterisks. 


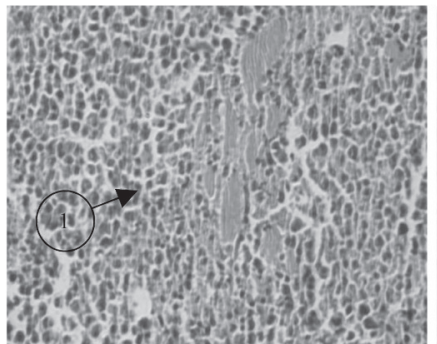

Model group

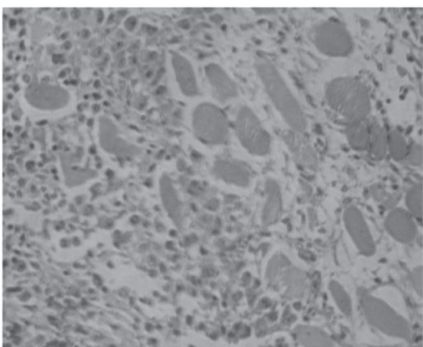

$5-\mathrm{FU}$

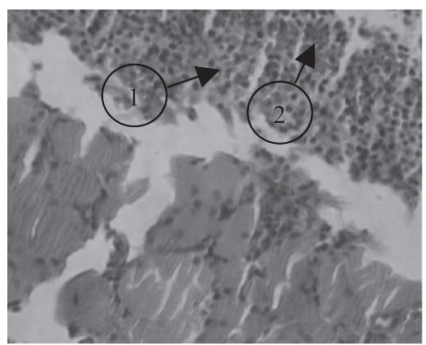

R-PE (LD)

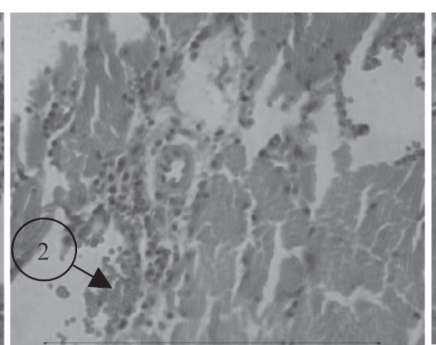

R-PE (MD)

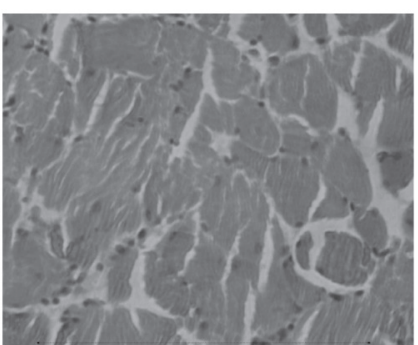

R-PE (HD)

Fig. 7 Histopathology and cytopathology of the S180sarcoma sections of the mice (tissues were stained with H\&E, 200×). (arrow 1) S180 sarcoma cells, (arrow 2) lymphocyte and phagocyte cells.

\section{DISCUSSION}

Phycoerythrin fluorescence properties are a consequence of interactions between covalently bound bilin chromophores and the apoprotein (21). Phycoerythrin was found to be sensitive to heat and light in aqueous solution and has strong fluorescence properties in vitro. Under laser irradiation (22), $\mathrm{R}-\mathrm{PE}$ can absorb and transmit the light to the surrounding oxygen and produce singlet and reactive oxygen species components. These light reaction products can kill cancer cells (23). Antitumor drugs screening by cancer cells has been widely adopted. In vitro experiments showed that R-PE has a significant inhibition on HeLa cells; this effect is obviously dose dependent and additional PDT treatment can obviously improve the effect.

Cell apoptosis is a kind of energy dependence and programmed cell death. Caspase, a member of the aspartic acid specific homocysteine protease (caspase) family, can degrade the antiapoptotic protein and induce the release of cytochrome $C$ of mitocondria. Caspase can also reduce the inhibitory effect of DNAase by ICAD (inhabitor of caspase DNAase) and improve the $\left[\mathrm{Ca}^{2+}\right]$ density of cells and activate the DNases, thus inducing cell apoptosis $(24,25)$. On the contrary, Bcl2 protein can inhibit cell apoptosis by reducing membrane permeability of the mitochondria and preventing the release of cytochrome $C$ (26). In vitro characterization studies revealed that exposure with R-PE to $632.8 \mathrm{~nm}$ laser light produced significant cytotoxicity on HeLa cells in a concentrationdependent manner. QRT-PCR studies showed that R-PE promoted the mRNA expression of caspase- 3 and caspase-10, but inhibited the mRNA expression of Bcl-2 in a concentrationdependent manner.

It is generally acknowledged that cellular immunity plays a leading role in anti-tumor immunity. Cellular immunity is mediated by sensitized $\mathrm{T}$ cells and lymphatic factor; its characteristic is the inflammation caused by cell infiltrating, and lymphocyte $\mathrm{T}$ cells, macrophages, and the mechanism of NK cells are the important effect cells (27). In vivo, R-PE can improve lymphocyte proliferation capacity, the kill activity of NK cells of tumor-bearing mice and inhibit tumor growth.

Tumor necrosis factor a (TNF-a) secreted by mononuclear macrophages can combine with TNFR I to induce cell apoptosis by the death structure domain of the cell. It can also increase the membrane surface molecules of cell apoptosis (FAS) to express and through the FAS/FASL pathway induce the cell apoptosis. Meanwhile, TNF-a can inhibit the angiogenesis of the tumor and obviously increased the kill activity of the LAK cells, tumor infiltrating lymphocyte cells and NK cells (28). The results from this study demonstrated that the anti-tumor effect of R-PE resulted through its anti-oxidative activity, improving apoptosis protease gene expression, immunity enhancement and promoting the secretion of the TNF- $\alpha$. Therefore R-PE could be a potential drug in the prevention of cancer.

\section{ACKNOWLEDGMENTS}

This work was sponsored by the Industry-UniversityResearch Collaboration program of Guangdong Province (No. 2010B090400461), Science and Technology Program of Guangdong Province and Shantou City(Nos. 2010B020201015 \& 2011-156).

\section{REFERENCES}

1 GIAZER A (1985) Light harvesting by phycobilisomes. Annual Review of Biophysics and Biophysical Chemistry 14: 47-77

2. ASHA, PARMA NIRA J, KUMAR SING H, AUANI KAUS HAL, DATTA MADAMWAR (2011) Characterization of an intact phycoerythrin and its cleaved $14 \mathrm{KDa}$ functional subunit from marine cyanobacterium phormidium sp. A27DM. Process Biochemistry 46: 1793-1799

3. CONTRERAS MARTEL C, MARTINEZ OYANEDEL J, BUNSTER M, LEGRAND P, PIRAS C, VERNEDE X, FONTECILLA CAMPS J (2001) Crystallization and 2.2Aresolution structure of R-phycoerythrin 
from Gracilaria chilensis: a case of perfect hemihedral twinning. Acta Crystallographica Section D: Biological Crystallography 57: 52-60.

4. SUN L, WANG SM, GONG XQ, ETAL (2009) Isolation, purification and characteristics of R-phycoerythrin from a marine macroalga heterosiphonia japonica.Protein Expres Purif 64(2): 146-154

5. SIBATA CH, COLUSSI VC, OLEINICK NL, KINSELLA TJ (2001) Photodynamic therapy in oncology. Exp Opin Pharmacother 2: 917-927.

6. HENDERSON BW, GOLLNICK SO (2003) Mechanistic principles of photodynamic therapy. In: Vo-DinH T, editor. Biomedical photonics Handbook. Boca Raton (FL): CRC Press 36.1-36.27

7. HUANG B, WANG GC, ZENG CK, LI ZG (2002) The experimental research of R-phycoerythrin subunits on cancer treatment.A new photosensitizer in PDT. Cancer Biother Radiopharm 17: 35-42

8. TRIESSC HEIJN M, BAAS P, SCHELLENS JHM, STEWRT FA (2006) Photodynamic therapy in oncology. Oncologist 11: 1034-1044

9. LING HU, BEI HUANG, MAN MAN ZUO, RUI YONG GUO, HAO WEI (2008) Preparation of the phycoerythrin subunit liposome in a Photodynamic experiment on liver cancer cells. Acta Pharmacol Sin 29(12): 1539-1546

10. GONZALO RODRÍGUEZ BERRIGUETE BS, LAURA GALVIS BS, BENITO FRAILE PHD, ETC (2012) Imnunoreactivity to caspase3 ,caspase-7,caspase- 8 and caspase- 9 forms is frequently lost in human prostate tumors.Human pathology 43: 229-237

11. AN CHIN CHENG, TZOU CHI HUANG, CHING SHU LAI, MIN HSIUNG PAN (2005) Induction of apoptosis by luteolin through cleavage of Bcl-2 family in human leukemia HL-60 cells. European Journal of Pharmacology 509: 1-10

12. MARYLA KRAJIEWSKA, ROBERT E, ROSENTHAL, JOWITA MIKOLJICZYK, HENNING R, STENNICKE, ETAL (2004) Early processing of Bid and caspase- $6,-8,-10,-14$ in the canine brain during cardiac arrest and resuscitation. Experimental Neurology 189: 261-279

13. TAPAS K, MAKAR, DAVID TRISLER, CHRISTOPHER T, BEVER, JAMES E, GOOLSBY, ETAL (2008) Stem cell based delivery of IFN- $\beta$ reduces relapses in experimental autoimmune encephalomyelitis. Journal of Neuroimmunology 196: 67-81

14. PAUL TAWA, ANDRE GIROUX, ERICH GRIMM, YONGXIN HAN, DONALD W, NICHOLSON, STEVEN, XANTHOUDAKIS (2006) Correlating the fractional inhibition of caspase-3 in NT2 cells with apoptotic markers using an active-caspase-3 enzyme-linked immunosorbent assay. Analytical Biochemistry 350: 32-40

15. GEFEI ZHOU, WEN XU SHENG, WEN HONG YAO, CHANG HAI WANG (2006) Effect of low molecular $\lambda$-carrageenan from chondrugs ocellatus on antitumor H-22 activity of 5-FU. Pharmacological Research 53: $129-134$
16. OING LI, YUKIYO HIRATA, SHUNAI PIAO, MASAYASU MINAMI (2000) Immunotoxicity of N,N-diethylaniline in mice: effect on natural killer activity, cytotoxic T lymphocyte activity, lymphocyte proliferation response and cellular components the spleen. Toxicology 150: 179-189

17. CESAR TEIJON, ROSA OLMO, MARIA DOLORES BLANCO, ARTURO ROMERO, JOSE MARIA TEIJON (2003) Effects of lead administration at low doses by different routes on rat spleens. Study of response of splenic lymphocytes and tissue lysozyme. Toxicology 191: 245-258

18. IVAN ZANONI, FRANCESCA GRANUCCI, MARIA FOTI, PAOLA RICCIARDI, CASTAGNOLI (2007) Self-tolerance dendritic cell(DC)mediated activation and tissue distribution of natural killer (NK) cells. Immunology Letters 110: 6-17

19. MONTIRONI R, VAN DER KUWAST T, BOCCON-GIBOD L, BONO AV, BOCCON-GIBOD L (2003) Handling and pathology reporting of radical prostatectomy specimens. Eururol 44(6): 626-636

20. LAWRENCE A, LACEY, DARLENE F, HOFFMANN, BRIAN FEDERICI A (2011) Histopathology and effect on development of the phopGV on larvae of the potato tubermoth, phthorimaea operculella(Lepidoptera:G elechiidae). Journal of invertebrate pathology 108: 52-55

21. ANDERSON LK, GROSSMAN AR (1990) Structure and light-regulated expression of phycoerythrin genes in wild-type and phycobilisome assembly mutants of synechocystis sp. Strain PCC 6701. J Bacteriol 172: 1297-1305

22. SANJIV K, MISHRA, ANUPAMA SHRIVASTAV, IMRANPANCHA, IE (2010) Effect of preservatives for good grade C-phycoerythrin, isolated from marine cyanobacteria Pseudanabaena sp. International Journal of Biological macromolecules 47: 597-602.

23. HE JA, HU YZ, JIANG L J (1997) Photodynamic action of phycobiliproteins: In situ generation of reactive oxygen species. Biochimica et Biophysica Acta-Bioenergetics 1320: 165-174.

24. GIRI A, NARASU M L (2000) Production of podophyllotoxin from podophyllum hex and rum: a potential natural product for clinically useful anticancer drugs. Cytotechnology 34: 17-26

25. LOGUE SE, MARTIN ST (2008) Caspase activation cascades in apoptosis. Biochem Soc Trans 36: 1-9

26. KIM NEWTON, ANDREAS STRASSER (1998) The Bcl-2 family and cell death regulation. Current opinion in Genetics \& Development 8: 68-75

27. JEFF J, SUBLESKI, ROBERT H, WILTROUT, JONATHAN M, WEISS (2009) Application of tissue-specific NK and NKT cell activity for tumor immunotherapy. Journal of Autoimmunity 33: 275-281

28. MICHAEL KARPUSAS, TERESA G, CACHERO, FANG QIAN, ANN BORIACK-SJODIN, COLLEEN MULLEN, ETAL (2002) Crystal Structure of Extracellular Human BAFF, a TNF family that stimulates B Lymphocytes. J.Mol.Biol 315:1145-1154 
